\title{
A modified reinforced clostridial medium for the isolation and enumeration of Lactobacillus delbrueckii ssp. bulgaricus in a mixed culture
}

\author{
Ayowole Oyeniran, ${ }^{1}$ @ Salam A. Ibrahim, ${ }^{1 *} \odot$ Rabin Gyawali, ${ }^{1} \odot$ Reza Tahergorabi, ${ }^{1}$ TahI Zimmerman, ${ }^{1}$ \\ and Albert Krastanov ${ }^{2}$ \\ ${ }^{1}$ Department of Food and Nutritional Sciences, North Carolina Agricultural and Technical State University, Greensboro 27411 \\ ${ }^{2}$ Department of Biotechnology, University of Food Technologies, 4002 Plovdiv, Bulgaria
}

\begin{abstract}
In this study, we modified reinforced clostridial medium (RCM) to selectively enumerate and isolate Lactobacillus delbrueckii ssp. bulgaricus, a probiotic and important starter culture in the dairy industry. The disparity in the reported carbohydrate fermentation pattern of L. delbrueckii ssp. bulgaricus was used to develop a growth medium not only selective for $L$. delbrueckii ssp. bulgaricus but significantly inhibitory to the growth of other lactic acid bacteria. A recently modified RCM (mRCM) was optimized for this study by the addition of $0.5 \%$ fructose, $0.5 \%$ dextrose, $1 \%$ maltose, and $0.25 \%$ sodium pyruvate while replacing lactose as a carbohydrate source. The cell recovery and bacterial counts of $L$. delbrueckii ssp. bulgaricus in tested products (pure L. delbrueckii ssp. bulgaricus strains, starter culture, probiotic supplements, and yogurt) using our mRCM with sodium pyruvate (mRCM-PYR) were significantly higher than in the recently modified RCM and the common de Man, Rogosa, and Sharpe (MRS) culture medium. The growth of other lactic acid bacteria (Streptococcus thermophilus, Lactobacillus acidophilus, Lactobacillus rhamnosus, and Lactobacillus reuteri) and Bifidobacteria was retarded in this modified medium compared with their growth in MRS and mRCM. This result is a significant improvement in the enumeration and differentiation of $L$. delbrueckii ssp. bulgaricus in mRCM-PYR compared with the results in MRS and mRCM where the high background growth of similar species interferes with the accuracy of bacterial population counts. Our results thus suggest that mRCM-PYR could be recommended as a reliable alternative growth medium for the selective enumeration and isolation of L. delbrueckii ssp. bulgaricus in a mixed culture.
\end{abstract}

Received November 11, 2019.

Accepted February 9, 2020.

*Corresponding author: ibrah001@ncat.edu
Key words: Lactobacillus bulgaricus, isolation, mixed culture, selective media, bacterial enumeration

\section{INTRODUCTION}

Lactobacillus delbrueckii ssp. bulgaricus is an important and highly regarded species of lactic acid bacteria due to its application in the production of several dairy products including yogurt, a fermented milk product that is well known for its health benefits (Zhu et al., 2010). Yogurt starter cultures require a symbiotic blend of L. delbrueckii ssp. bulgaricus and Streptococcus thermophilus in approximately equal amounts to obtain the desired organoleptic properties that result from the metabolic activity of both microorganisms during their growth in milk. Consequently, the final quality of yogurt can suffer with regard to texture, acidity, and flavor if this proper bacterial balance is not achieved (Lourens-Hattingh and Viljoen, 2001).

The probiotic potential of L. delbrueckii ssp. bulgaricus has been mentioned in several studies (Singh et al., 1979; Mahmood, et al., 2015; Pescuma et al., 2015), and as with any probiotic, it confers various health benefits to the host when administered at an effective dose. Consequently, in order for L. delbrueckii ssp. bulgaricus to play its role as a probiotic, the requisite bacterial population levels are critical. To support the quality of yogurt, many countries have adopted standards for these viable bacteria numbers and the ratio of $L$. delbrueckii ssp. bulgaricus to Streptococcus thermophilus. For example, the Codex Alimentarius, a collection of internationally recognized standards for food production, and most other national regulatory agencies in the US have established a minimum level of $1 \times 10^{7} \mathrm{cfu} / \mathrm{g}$ of yogurt starter microorganisms. Other countries such as France, Switzerland, Italy, and Spain have also agreed to follow the Codex Alimentarius recommendation of a minimum level of yogurt starter microorganisms at the time of consumption. However, in the United Kingdom, a minimum requirement of 10 million viable lactobacilli per $\mathrm{mL}$ of yogurt at the time of sale was established 
(Davis and McLachlan, 1974; Robinson and Tamime, 1976; Hamann and Marth, 1984).

The current standard medium, de Man, Rogosa, and Sharpe (MRS), is unreliable as a selective method for enumerating $L$. delbrueckii ssp. bulgaricus species in mixed bacterial cultures as true counts are often imprecise due to the presence of high background colonies of similar species. Other media proposed for the selective enumeration of specific lactic acid bacteria (Matalon and Sandine, 1986; Ghoddusi and Robinson, 1996; Yamani and Ibrahim, 1996; Tabasco et al., 2007; Galat et al., 2016; Hayek et al., 2019) also struggle to selectively enhance the growth of $L$. delbrueckii ssp. bulgaricus in the presence of other lactic acid bacteria. A modified reinforced clostridial medium (mRCM) by Nwamaioha and Ibrahim (2018) recently showed remarkable results in the differentiation and enumeration of 2 strains of $L$. delbrueckii ssp. bulgaricus in a mixed bacterial culture by giving distinct and large colonies. This culture medium supports the growth of lactic acid bacteria other than L. delbrueckii ssp. bulgaricus but still makes the isolation and enumeration steps required for L. delbrueckii ssp. bulgaricus very challenging. Nevertheless, preliminary studies have demonstrated that mRCM can be optimized to improve the recovery of stressed bacterial cells and select for a broader range of $L$. delbrueckii ssp. bulgaricus strains. Therefore, the objective of this study was to examine the modification of reinforced clostridial medium (RCM) for the isolation and enumeration of L. delbrueckii ssp. bulgaricus from a mixed culture.

\section{MATERIALS AND METHODS}

\section{Source of L. delbrueckii ssp. bulgaricus}

A total of 32 sources of L. delbrueckii ssp. bulgaricus strains were used in the study (Table 1). Eleven strains of freeze-dried L. delbrueckii ssp. bulgaricus cultures intended for industrial production of fermented milk products were supplied by Albert Krastanov (Department of Biotechnology, University of Food Technologies, Plovdiv, Bulgaria). Six yogurt starter cultures and 3 probiotic supplements from Europe were selected. All

Table 1. Description of samples used

\begin{tabular}{|c|c|c|c|c|}
\hline No. & $\begin{array}{l}\text { Product } \\
\text { code }\end{array}$ & Sample & Source & Bacterial composition as labeled \\
\hline 1 & $\mathrm{~S} 28$ & Pure industrial strain & Bulgaria & Lactobacillus bulgaricus \\
\hline 2 & S6 & Pure industrial strain & Bulgaria & L. bulgaricus \\
\hline 3 & S19 & Pure industrial strain & Bulgaria & L. bulgaricus \\
\hline 4 & S8 & Pure industrial strain & Bulgaria & L. bulgaricus \\
\hline 5 & LB6 & Pure industrial strain & Bulgaria & L. bulgaricus \\
\hline 6 & S1 & Pure industrial strain & Bulgaria & L. bulgaricus \\
\hline 7 & LB9 & Pure industrial strain & Bulgaria & L. bulgaricus \\
\hline 8 & $\mathrm{~S} 22$ & Pure industrial strain & Bulgaria & L. bulgaricus \\
\hline 9 & S9 & Pure industrial strain & Bulgaria & L. bulgaricus \\
\hline 10 & S7 & Pure industrial strain & Bulgaria & L. bulgaricus \\
\hline 11 & S5 & Pure industrial strain & Bulgaria & L. bulgaricus \\
\hline 12 & ST11 & Starter culture & Bulgaria & $\begin{array}{l}\text { Streptococcus thermophilus, L. bulgaricus, Lactobacillus } \\
\text { rhamnosus }\end{array}$ \\
\hline 13 & ST12 & Starter culture & Bulgaria & S. thermophilus, L. bulgaricus \\
\hline 14 & ST13 & Starter culture & Bulgaria & S. thermophilus, L. bulgaricus \\
\hline 15 & ST14 & Starter culture & Bulgaria & S. thermophilus, L. bulgaricus \\
\hline 16 & ST15 & Starter culture & Canada & S. thermophilus, L. bulgaricus, Lactobacillus acidophilus \\
\hline 17 & ST16 & Starter culture & Bulgaria & S. thermophilus, L. bulgaricus \\
\hline 18 & SP17 & Probiotic supplement & Bulgaria & S. thermophilus, L. bulgaricus, Lactobacillus reuteri \\
\hline 19 & SP18 & Probiotic supplement & Bulgaria & S. thermophilus, L. bulgaricus \\
\hline 20 & SP19 & Probiotic supplement & Bulgaria & S. thermophilus, L. bulgaricus, L. rhamnosus \\
\hline 21 & SP8 & Yogurt & Spain & S. thermophilus, L. bulgaricus, Bifidobacterium, L. reuteri \\
\hline 22 & SP9 & Yogurt & Spain & Live and active cultures \\
\hline 23 & SP10 & Yogurt & Spain & Live and active cultures \\
\hline 24 & E1A & Yogurt & The Netherlands & S. thermophilus, L. bulgaricus, L. acidophilus, Bifidobacterium \\
\hline 25 & $\mathrm{E} 2 \mathrm{Z}$ & Yogurt & The Netherlands & Live and active culture \\
\hline 26 & E3D & Yogurt & Spain & Live and active culture \\
\hline 27 & $\mathrm{E} 4 \mathrm{P}$ & Yogurt & Bulgaria & Live and active culture \\
\hline 28 & $\mathrm{~L} 6 \mathrm{~N}$ & Yogurt & United States & $\begin{array}{l}\text { S. thermophilus, L. bulgaricus, Bifidobacterium lactis, L. } \\
\text { acidophilus, L. rhamnosus }\end{array}$ \\
\hline 29 & BY2 & Yogurt & Bulgaria & L. bulgaricus, other live culture \\
\hline 30 & $\mathrm{BY} 4$ & Yogurt & Bulgaria & L. bulgaricus, other live culture \\
\hline 31 & BY5 & Yogurt & Bulgaria & L. bulgaricus, other live culture \\
\hline 32 & BY6 & Yogurt & Bulgaria & L. bulgaricus, other live culture \\
\hline
\end{tabular}


samples were maintained at $-20^{\circ} \mathrm{C}$ until further use. In addition, 12 yogurt samples were obtained from Europe and stored under refrigeration until further use.

\section{Chemicals and Reagents}

All chemicals and reagents used in this study were purchased from Fisher Scientific (Pittsburgh, PA).

\section{Lactobacilli MRS Agar Medium}

A lactobacilli MRS agar medium was prepared by dissolving $55 \mathrm{~g}$ of MRS broth (Neogen Co., Lansing, $\mathrm{MI})$ and $0.5 \mathrm{~g}$ of L-cysteine in $1 \mathrm{~L}$ of deionized distilled water (DDW), and the resultant solution was stirred well until all particles were completely dissolved. Agar powder (15 g; Neogen) was added, and the agar medium was sterilized at $121^{\circ} \mathrm{C}$ for $15 \mathrm{~min}$ and then cooled in a water bath.

\section{Modified Reinforced Clostridial Medium}

Modified RCM was prepared according to the method of Nwamaioha and Ibrahim (2018) by completely dissolving $10 \mathrm{~g}$ of proteose peptone \#3,10 $\mathrm{g}$ of beef extract, $5 \mathrm{~g}$ of yeast extract, $10 \mathrm{~g}$ of lactose, $5 \mathrm{~g}$ of sodium chloride, $3 \mathrm{~g}$ of sodium acetate, $2 \mathrm{~g}$ of $\mathrm{K}_{2} \mathrm{HPO}_{4}$, $0.1 \mathrm{~g}$ of uracil, $0.25 \mathrm{~g}$ of calcium chloride, $0.2 \%$ Tween 80 , and $0.5 \mathrm{~g}$ of L-cysteine in $1 \mathrm{~L}$ of DDW. This solution was adjusted to a final $\mathrm{pH}$ of $6.0 \pm 0.2$ using $6 \mathrm{M}$ $\mathrm{HCl}$ before the addition of $0.01 \%$ aniline blue and $15 \mathrm{~g}$ of agar. This medium was then autoclaved at $121^{\circ} \mathrm{C}$ for 15 min and cooled in a water bath.

\section{Modified Reinforced Clostridial Medium-Pyruvate}

A reinforced clostridial medium was optimized for selectivity and accurate enumeration of $L$. delbrueckii ssp. bulgaricus by dissolving $10 \mathrm{~g}$ of peptone \#3, 10 $\mathrm{g}$ of beef extract, $5 \mathrm{~g}$ of yeast extract, $5 \mathrm{~g}$ of sodium chloride, $3 \mathrm{~g}$ of sodium acetate, $2 \mathrm{~g}$ of $\mathrm{K}_{2} \mathrm{HPO}_{4}, 0.1 \mathrm{~g}$ of uracil, $0.25 \mathrm{~g}$ of calcium chloride, $5 \mathrm{~g}$ of dextrose, 5 $\mathrm{g}$ of fructose, $10 \mathrm{~g}$ of maltose, $2 \mathrm{~g}$ of sodium pyruvate, $0.2 \%$ Tween 80 , and $0.5 \mathrm{~g}$ of L-cysteine in $1 \mathrm{~L}$ of DDW. This solution was adjusted to a final $\mathrm{pH}$ of $6.0 \pm 0.2$ using $6 \mathrm{M} \mathrm{HCl}$ before the addition of $0.008 \%$ aniline blue and $15 \mathrm{~g}$ of agar. The medium was autoclaved at $121^{\circ} \mathrm{C}$ for 15 min and then cooled in a water bath. All freshly prepared media in this study were poured into sterile Petri dishes and stored at $4^{\circ} \mathrm{C}$ until needed. The difference in the carbohydrate sources of $\mathrm{mRCM}$ and modified reinforced clostridial medium-pyruvate (mRCM-PYR) is highlighted in Table 2.

\section{Enumeration of L. delbrueckii ssp. bulgaricus in Pure Industrial Strains, Yogurt Starter Culture, and Probiotic Supplements}

For the enumeration of $L$. delbrueckii ssp. bulgaricus in these products, $0.1 \mathrm{~g}$ of freeze-dried samples was measured and transferred into $3 \mathrm{~mL}$ of skim milk with the addition of $10 \mu \mathrm{L}$ of Tween 80 and $0.1 \mathrm{~mL}$ of yeast extract to enhance the recovery of stressed bacterial cells. This mix was fermented at $44^{\circ} \mathrm{C}$ for $7 \mathrm{~h}$, at which point the skim milk curdled. The curdled milk was shaken, and $1 \mathrm{~mL}$ was transferred for serial dilution into a $9 \mathrm{~mL}$ of peptone solution. Aliquots $(100 \mu \mathrm{L})$ of appropriate dilutions were plated in duplicates onto the 3 culture media (MRS, mRCM, and optimized RCM) for the enumeration of $L$. delbrueckii ssp. bulgaricus. The inoculated plates were incubated for $72 \mathrm{~h}$ at $44^{\circ} \mathrm{C}$ in anaerobe chambers, and the colonies were counted using a Quebec colony counter (Fisher Scientific).

\section{Enumeration of L. delbrueckii ssp. bulgaricus in Commercial Yogurt Samples}

Dilutions of yogurt samples were prepared by adding $10 \mathrm{~g}$ of each sample to a screw-capped bottle containing $90 \mathrm{~mL}$ of deionized water and then properly shaking the mixture. This mixture was placed in an incubator at $44^{\circ} \mathrm{C}$ for 15 min to repair weak and damaged cells. Subsequent dilutions of up to $10^{-7}$ were made in a $0.1 \%$ peptone solution and vortexed well between transfers. Aliquots $(100 \mu \mathrm{L})$ of appropriate dilutions were then plated in duplicate onto the 3 culture media (MRS, mRCM, and optimized RCM) for the enumeration of

Table 2. Composition of modified reinforced clostridial medium (mRCM) and modified reinforced clostridial medium-pyruvate (mRCM-PYR)

\begin{tabular}{ll}
\hline mRCM & mRCM-PYR \\
\hline $10 \mathrm{~g}$ of proteose peptone \#3 & $10 \mathrm{~g}$ of proteose peptone $\# 3$ \\
$10 \mathrm{~g}$ of beef extract & $10 \mathrm{~g}$ of beef extract \\
$5 \mathrm{~g}$ of yeast extract & $5 \mathrm{~g}$ of yeast extract \\
$5 \mathrm{~g}$ of sodium chloride & $5 \mathrm{~g}$ of sodium chloride \\
$0.25 \mathrm{~g}$ of calcium chloride & $0.25 \mathrm{~g}$ of calcium chloride \\
$3 \mathrm{~g}$ of sodium acetate & $3 \mathrm{~g}$ of sodium acetate \\
$2 \mathrm{~g}$ of ammonium phosphate & $2 \mathrm{~g}$ of ammonium phosphate \\
dibasic & dibasic \\
$0.5 \mathrm{~g}$ of L-cysteine & $0.5 \mathrm{~g}$ of L-cysteine \\
$0.1 \mathrm{~g}$ of uracil & $0.1 \mathrm{~g}$ of uracil \\
$0.01 \%$ aniline blue & $0.008 \%$ aniline blue \\
$0.2 \%$ Tween 80 & $0.2 \%$ Tween 80 \\
$10 \mathrm{~g}$ of lactose & $5 \mathrm{~g}$ of dextrose ${ }^{1}$ \\
& $5 \mathrm{~g}$ of fructose \\
& $10 \mathrm{~g}$ of maltose \\
& $2 \mathrm{~g}$ of sodium pyruvate ${ }^{1}$ \\
\hline
\end{tabular}

${ }^{1}$ Carbohydrate sources. 
L. delbrueckii ssp. bulgaricus. The inoculated plates were incubated for $72 \mathrm{~h}$ at $44^{\circ} \mathrm{C}$ in anaerobe $\left(\mathrm{CO}_{2} /\right.$ $\mathrm{N}_{2}$ ) chambers (Labconco, Kansas City, MO), and the colonies were counted using a Quebec colony counter (Fisher Scientific).

\section{Enumeration of L. delbrueckii ssp. bulgaricus in Traditional Bulgarian Yogurt}

To enumerate L. delbrueckii ssp. bulgaricus in traditional Bulgarian yogurt, $5 \mathrm{~mL}$ of samples was measured and transferred into $45 \mathrm{~mL}$ of skim milk with $2 \mathrm{~mL}$ of yeast extract (20\%) added to repair damaged and stressed bacterial cells. This mix was fermented at $44^{\circ} \mathrm{C}$ for $7 \mathrm{~h}$, at which point the skim milk curdled. The curdled milk was stirred, and $10 \mathrm{~mL}$ was sampled for the enumeration of bacterial cells following the method outlined for the enumeration of L. delbrueckii ssp. bulgaricus in yogurt samples.

\section{Statistical Analyses}

The SAS version 9.4 (SAS Institute Inc., Cary, NC) was used to analyze the experiment data obtained in this study. One-way ANOVA was used to determine significant differences between the values. Significant differences $(P<0.05)$ between means of bacterial counts $(\mathrm{cfu} / \mathrm{g})$ were compared using Tukey's test. Bacterial population counts were converted to $\log _{10}$ transformation before analysis.

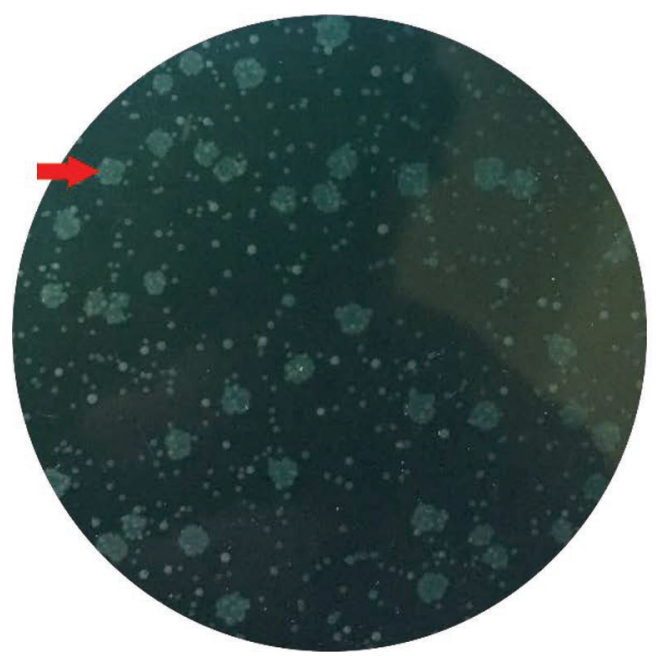

\section{RESULTS}

\section{Preliminary Study}

In preliminary studies, the effect of different carbon sources on the morphology of L. delbrueckii ssp. bulgaricus colonies was evaluated. We observed that the use of $2 \%$ sodium citrate and $1 \%$ sodium pyruvate as alternatives to a proteose peptone diluent solution not only produced more prominent and distinguishable colonies in the previously modified RCM by Nwamaioha and Ibrahim (2018) but also improved the bacterial count (data not shown). Our findings also showed that sodium pyruvate retarded the growth of lactic acid bacteria other than L. delbrueckii ssp. bulgaricus, which otherwise grew when $2 \%$ sodium citrate and $0.1 \%$ proteose peptone were used as diluent media. These observations would suggest that the inclusion of sodium pyruvate as a component in a growth medium could improve the recovery of injured or damaged bacterial cells. Further tests employed various concentrations of individual and combined treatments of fructose, maltose, dextrose, lactose, sodium citrate, and sodium pyruvate as components of mRCM. Initially, a combined treatment of $0.5 \%$ dextrose, $0.5 \%$ fructose, $1 \%$ maltose, and $1 \%$ sodium pyruvate replacing $1 \%$ lactose as a carbon source in mRCM appeared to be the most effective at selecting only for L. delbrueckii ssp. bulgaricus in the mixed bacterial culture. However, it became evident during the screening that a reduced concentration of sodium pyruvate would be needed to be effective in improving the selectivity of the modified medium. A $1 \%$

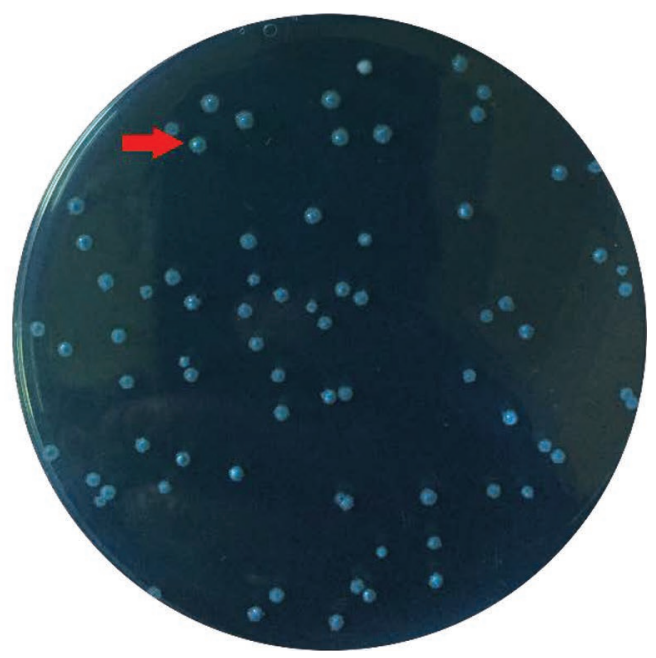

Figure 1. The red arrow shows a rough-edged Lactobacillus bulgaricus colony in modified reinforced clostridial medium (mRCM; left image) morph into a round and smooth colony in modified reinforced clostridial medium-pyruvate (mRCM-PYR) having a concentration of $1 \%$ sodium pyruvate. 
sodium pyruvate concentration in this growth medium composition not only retarded other bacterial growth but also converted the characteristic rough-edge morphology of the surviving $L$. delbrueckii ssp. bulgaricus colonies to a smooth one (Figure 1). Thus, a combination of $0.5 \%$ dextrose, $0.5 \%$ fructose, $1 \%$ maltose, and $0.2 \%$ sodium pyruvate as carbon sources in our growth medium proved to be the most effective at improving the morphology and cell recovery of $L$. delbrueckii ssp. bulgaricus colonies.

\section{Cell Repair and Recovery}

The L. delbrueckii ssp. bulgaricus colonies that were isolated from freeze-dried probiotic supplements on MRS, mRCM, and mRCM-PYR growth media are shown in Figure 2. The SP18 cell colonies (L. delbrueckii ssp. bulgaricus circled in red) appear small and fragile in both the MRS and mRCM, suggesting that the cells were stressed or injured; however, this was not the case in mRCM-PYR where the L. delbrueckii ssp.

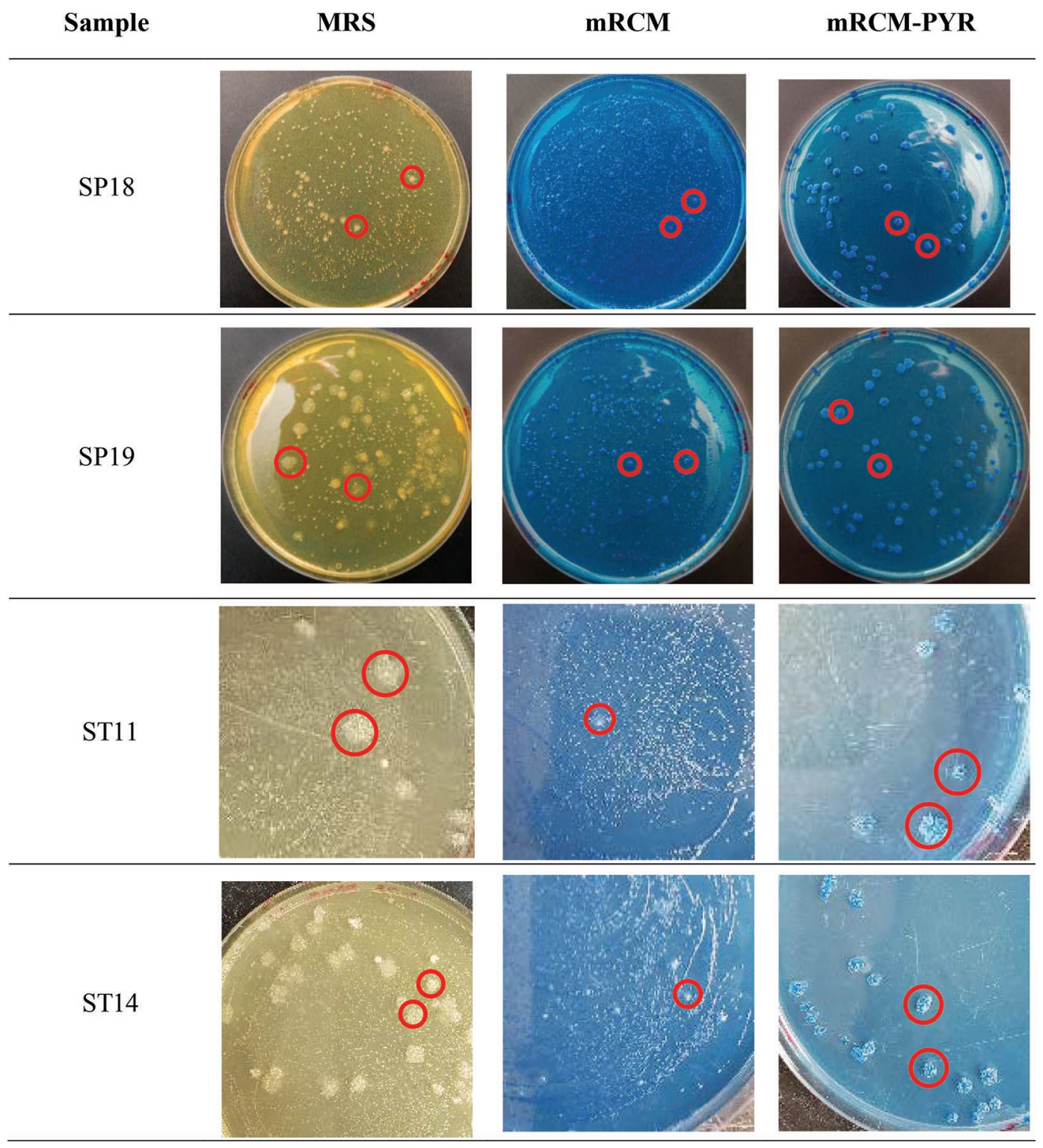

Figure 2. Morphology of Lactobacillus bulgaricus colonies (circled in red) on de Man, Rogosa, and Sharpe (MRS) medium, modified reinforced clostridial medium (mRCM), and modified reinforced clostridial medium-pyruvate (mRCM-PYR). See Table 1 for sample description. 
bulgaricus cells appeared as large colonies. The result for SP19 further highlighted the advantage of using the mRCM-PYR growth media over the previously modified RCM with regard to the repair of damaged or stressed microbial cells. Nonlethal injury to bacterial cells can occur for several reasons. For example, the destruction of bacterial cells as a result of exposure to low temperatures in the form of freeze drying, freezing/ thawing, and prolonged storage at low temperatures is common in the industrial production of probiotic supplements and starter cultures.

The cell colonies in mRCM were the smallest while the mRCM-PYR culture media facilitated the optimum growth and repair of $L$. delbrueckii ssp. bulgaricus cells, resulting in larger colonies. Similar results were noted with other starter cultures that were evaluated for the viability of $L$. delbrueckii ssp. bulgaricus. For instance, in the previously modified RCM growth media, the colonies of L. delbrueckii ssp. bulgaricus in samples ST 11 and ST 14 were tiny and very difficult to identify in the presence of other bacteria colonies. In contrast to the mRCM, our optimized RCM produced visible and large colonies for the same samples, and the growth of other bacteria was significantly inhibited (Figure 2).

\section{Selective Growth and Enumeration of Pure L. delbrueckii ssp. bulgaricus Strains}

The bacterial counts of 11 pure L. delbrueckii ssp. bulgaricus strains are presented in Figure 3. The
mRCM-PYR performed significantly better than MRS and $\mathrm{mRCM}(P<0.05)$ in 6 of the strains $(\mathrm{S} 6, \mathrm{~S} 19$, LB9, S9, S7, and S5) as measured by the bacterial populations. No significant difference was observed in the bacterial counts recorded in $\mathrm{mRCM}$ and $\mathrm{mRCM}-\mathrm{PYR}$ in 4 L. delbrueckii ssp. bulgaricus strains (S28, S8, S1, and S22). However, both growth media performed significantly better than MRS $(P<0.05)$ in these strains. The only case in which MRS performed noticeably better $(P<0.05)$ than mRCM-PYR and mRCM was with L. delbrueckii ssp. bulgaricus strain LB6. The effect of the 3 media on the morphology of $L$. delbrueckii ssp. bulgaricus colonies is shown in Figure 4.

\section{Selective Enumeration and Differentiation of L. delbrueckii ssp. bulgaricus in Mixed Cultures}

The bacterial counts of L. delbrueckii ssp. bulgaricus recovered from 21 products using MRS, mRCM, and mRCM-PYR are presented in Figure 5. The 21 products consisted of a starter culture, probiotic supplements, and yogurt and contained mixed bacterial cultures. The 3 media had similar effects on the bacterial counts of 4 products (E1A, BY2, BY4, and SP8). No significant difference was observed in the bacterial counts in mRCM and mRCM-PYR for 6 products (E2Z, L6N, BY5, ST12, SP17, and SP19). However, both growth media performed significantly better than MRS $(P<$ $0.05)$ in these products. The mRCM-PYR performed better than MRS and mRCM $(P<0.05)$ in 10 prod-

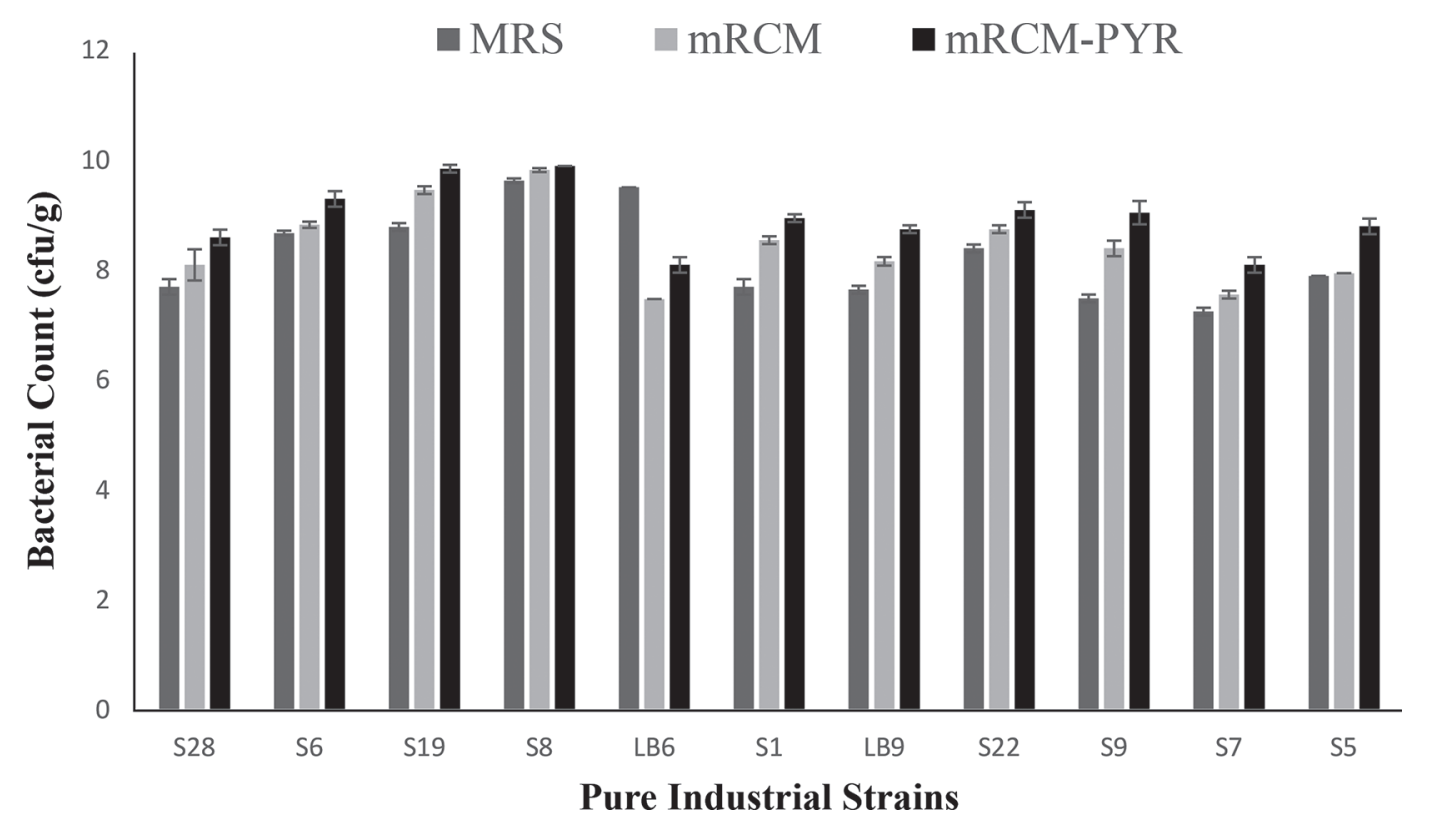

Figure 3. Bacterial count of 11 pure Lactobacillus bulgaricus strains on de Man, Rogosa, and Sharpe (MRS) medium, modified reinforced clostridial medium (mRCM), and modified reinforced clostridial medium-pyruvate (mRCM-PYR) at $44^{\circ} \mathrm{C}$ after $72 \mathrm{~h}$ of anaerobic incubation. Error bars indicate SD for an experiment performed in duplicate. 


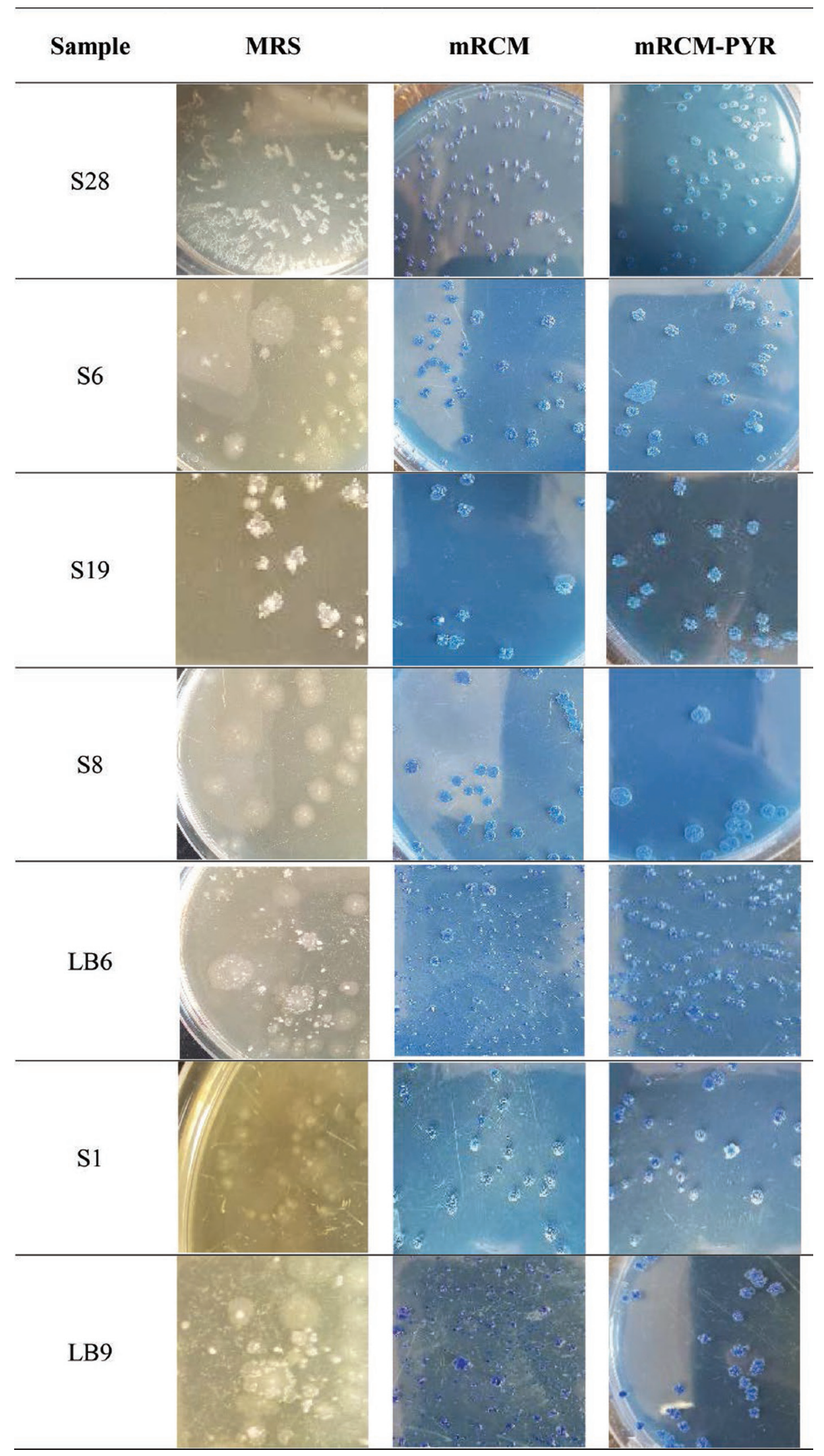

Figure 4. Morphology of pure Lactobacillus bulgaricus strains on de Man, Rogosa, and Sharpe (MRS) medium, modified reinforced clostridial medium (mRCM), and modified reinforced clostridial medium-pyruvate (mRCM-PYR) after anaerobic incubation at $44^{\circ} \mathrm{C}$ for $72 \mathrm{~h}$. 
ucts (E3D, BY6, SP9, ST11, ST14, SP10, ST13, ST15, ST16, and SP18). The bacterial counts of L. delbrueckii ssp. bulgaricus in E4P were similar in mRCM-PYR and MRS but considerably higher than those in $\mathrm{mRCM}(P$ $<0.05)$. The results thus confirmed the effectiveness of our growth medium, mRCM-PYR, as a suitable alternative to MRS and $\mathrm{mRCM}$ in the selective enumeration and isolation of L. delbrueckii ssp. bulgaricus in mixed bacterial cultures. Figure 6 shows the morphology of L. delbrueckii ssp. bulgaricus in mixed cultures. The colonies of $L$. delbrueckii ssp. bulgaricus in mRCM-PYR were easy to identify and enumerate as the growth of other lactic acid bacteria was highly retarded. The identification of colonies was confirmed using direct microscopic observation and the PCR method.

\section{DISCUSSION}

In a previous study by Nwamaioha and Ibrahim (2018), a growth medium was modified to selectively enhance the isolation and enumeration of $L$. delbrueckii ssp. bulgaricus in dairy products. In the present study, we further modified this medium for the superior selectivity and enumeration of L. delbrueckii ssp. bulgaricus by replacing lactose with $0.5 \%$ dextrose, $0.5 \%$ fructose, $1 \%$ maltose, and $0.2 \%$ sodium pyruvate. Various carbohydrates that are the primary energy source for bacteria in growth media have been used to selectively enumerate lactic acid bacteria. For example, Tabasco et al. (2007) supplemented MRS with fructose to enumerate $L$. delbrueckii ssp. bulgaricus. Another justification

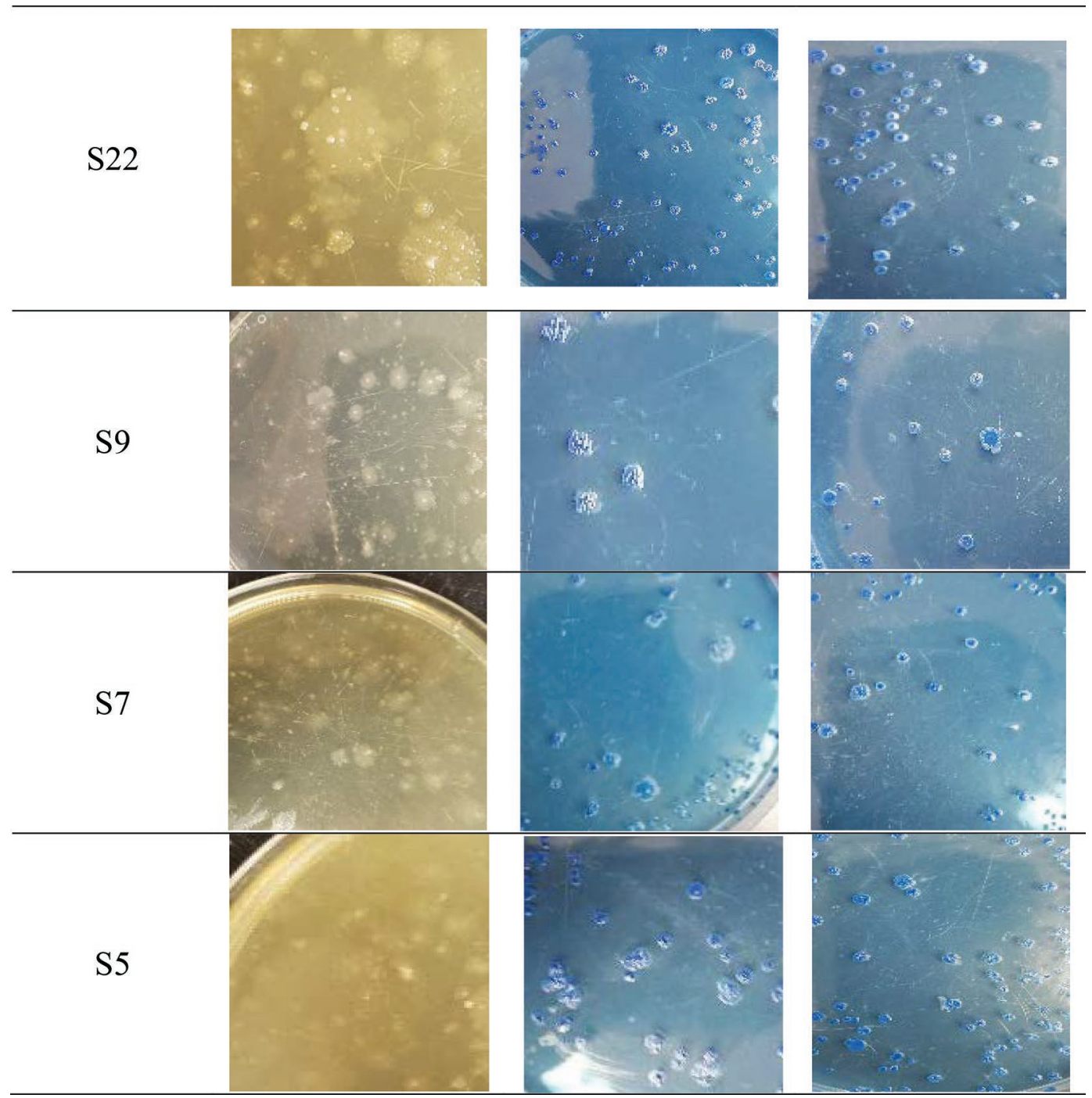

Figure 4 (Continued). Morphology of pure Lactobacillus bulgaricus strains on de Man, Rogosa, and Sharpe (MRS) medium, modified reinforced clostridial medium $(\mathrm{mRCM})$, and modified reinforced clostridial medium-pyruvate (mRCM-PYR) after anaerobic incubation at $44^{\circ} \mathrm{C}$ for $72 \mathrm{~h}$. 
for the use of different carbon sources is the disparity in the reported carbohydrate use in $L$. delbrueckii ssp. bulgaricus. The inconsistencies recorded in the use of fructose, mannose, and maltose among other sugars in $L$. delbrueckii ssp. bulgaricus have been attributed to strain type and composition of the growth medium (Zourari et al., 1992; Chervaux et al., 2000; Yuksekdag and Aslim, 2008; Li et al., 2016). The mRCM-PYR was developed to optimally enumerate and select for L. delbrueckii ssp. bulgaricus regardless of the source and strain type. We observed that the combination of carbon sources was responsible for the selectivity and high bacterial counts in mRCM-PYR. However, the substitution or elimination of any of the carbon sources, particularly sodium pyruvate, did not yield the same result. Pyruvate is an essential intermediate in the metabolism of lactic acid bacteria and can be converted into several end products such as acetic acid, formic acid, and lactic acid. Higashio et al. (1977) attributed the stimulatory effect that $S$. thermophilus had on the growth of L. delbrueckii ssp. bulgaricus to the production of formic and pyruvic acids. Polak-Berecka et al. (2010) recorded a better yield of cell biomass when sodium pyruvate was combined with glucose as carbon sources. These results might help to explain the importance of pyruvate in the cell repair and recovery observed in this study.

Many of the medium available in the literature such as MRS (de Man et al., 1960), Lee's agar (Lee et al., 1974), yogurt lactic agar (Matalon and Sandine, 1986), reinforced clostridial Prussian blue (Ghoddusi and Robinson, 1996), and bromocresol green whey agar (Yamani and Ibrahim, 1996) have not been able to selectively enhance the growth of $L$. delbrueckii ssp. bulgaricus in a mixed culture. The mRCM-PYR performed well in the enumeration of $L$. delbrueckii ssp. bulgaricus in a mixed culture while retarding the growth of other lactic acid bacteria. This is an improvement over the previous study by Nwamaioha and Ibrahim (2018) where a lack of significant differences in bacterial counts coupled with the growth of other lactic acid bacteria was recorded in the tested products.

Further study may subject L. delbrueckii ssp. bulgaricus strains isolated in this study using mRCM-PYR to genotypic methods of identification with a view to discovering relationships between the origins of various strains. The enzyme activity, secreted proteins, aroma production, and stress resistance of the various strains should also be tested and compared. In addition, understanding of the pyruvate metabolism is critical to demonstrate the applications and health benefits of $L$. delbrueckii ssp. bulgaricus. This additional exploration could lead to the identification and isolation of superior probiotic and industrial strains.

\section{CONCLUSIONS}

Our results demonstrated that mRCM-PYR modified by the addition of sodium pyruvate, fructose, and maltose was effective in selectively isolating and

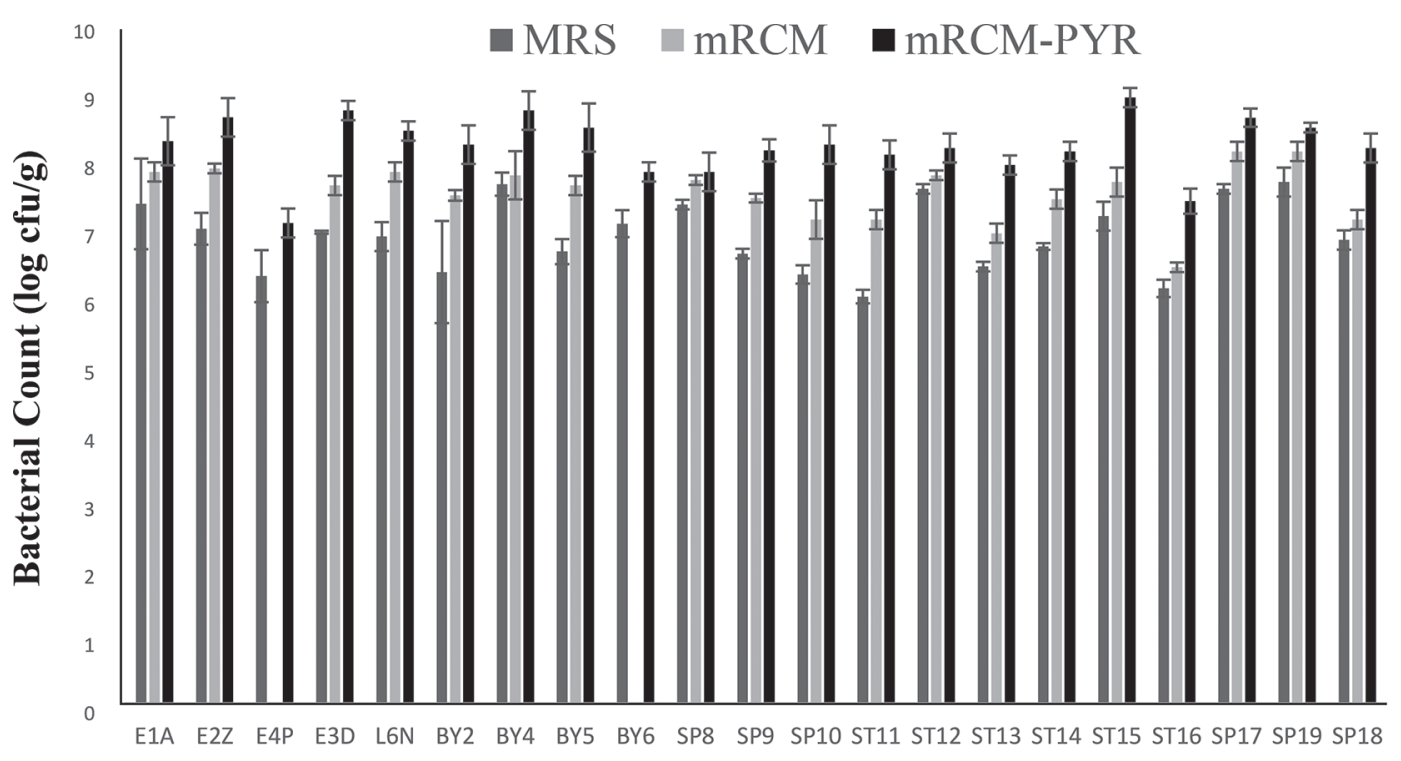

Mixed Bacterial Culture

Figure 5. Bacterial count of Lactobacillus bulgaricus in mixed culture on de Man, Rogosa, and Sharpe (MRS) medium, modified reinforced clostridial medium (mRCM), and modified reinforced clostridial medium-pyruvate (mRCM-PYR) at $44^{\circ} \mathrm{C}$ after $72 \mathrm{~h}$ of anaerobic incubation. Error bars indicate SD for an experiment performed in duplicate. 


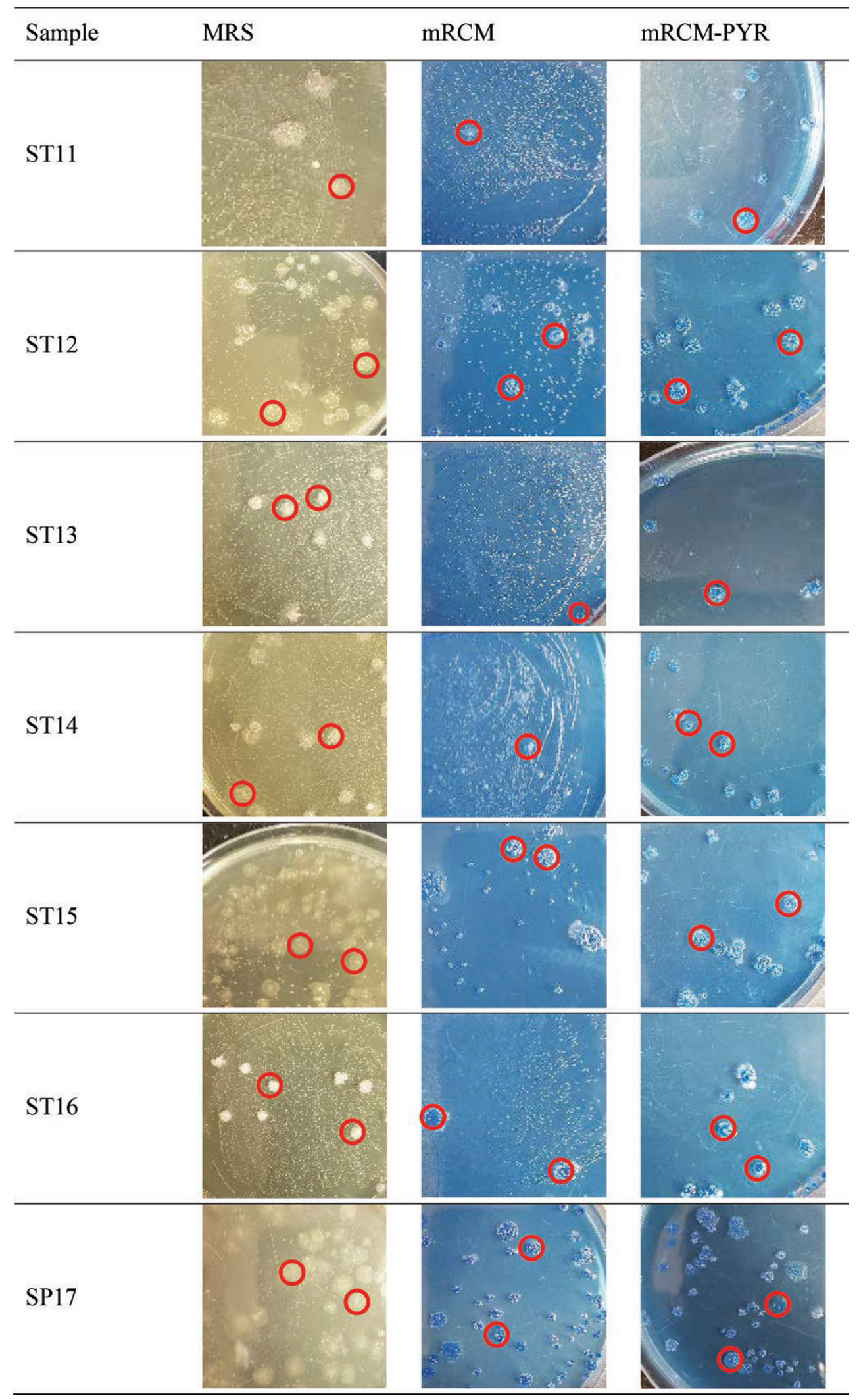

Figure 6. Morphology of Lactobacillus bulgaricus (circled) in mixed culture on de Man, Rogosa, and Sharpe (MRS) medium, modified reinforced clostridial medium (mRCM), and modified reinforced clostridial medium-pyruvate (mRCM-PYR) after anaerobic incubation at $44^{\circ} \mathrm{C}$ for $72 \mathrm{~h}$. 


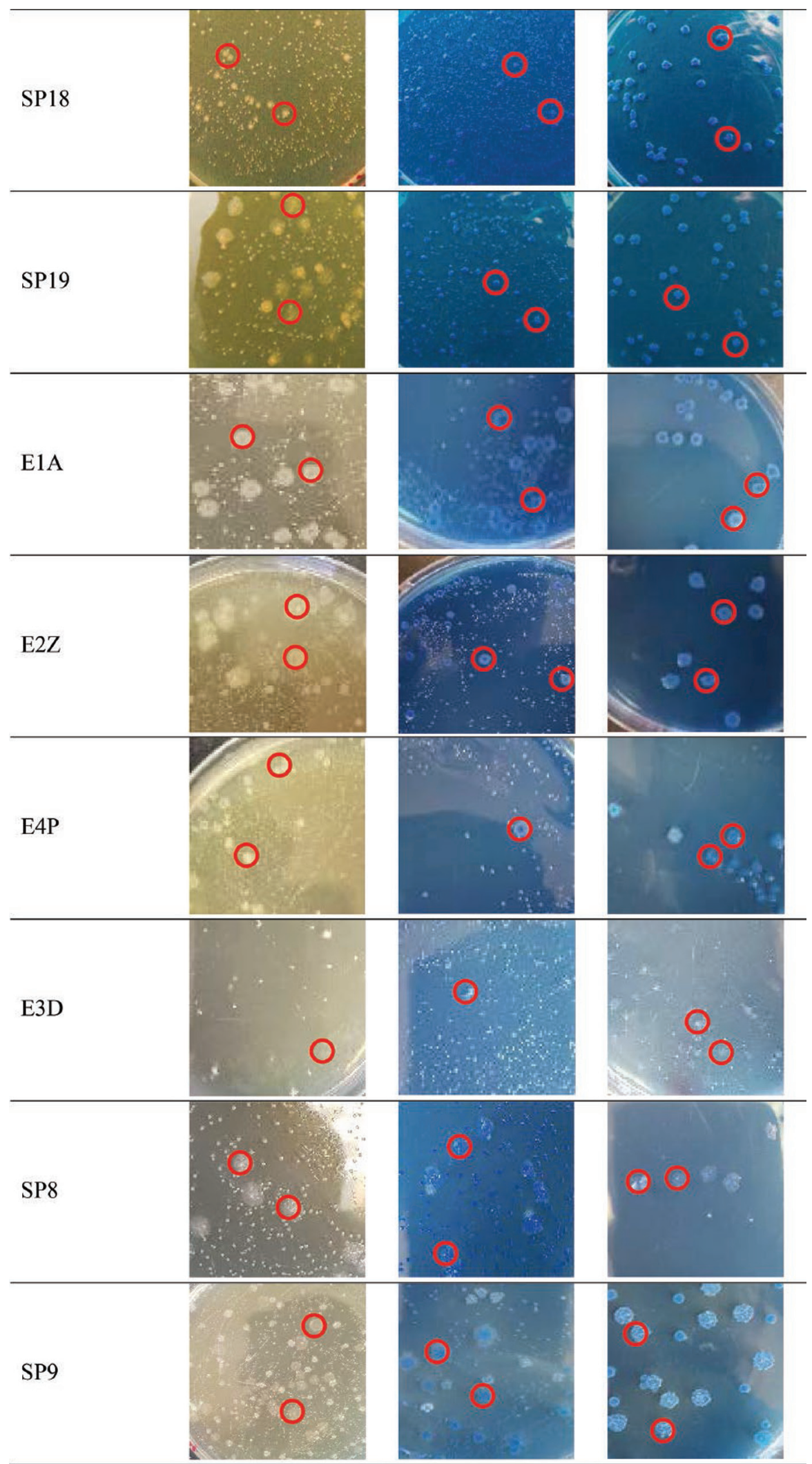

Figure 6 (Continued). Morphology of Lactobacillus bulgaricus (circled) in mixed culture on de Man, Rogosa, and Sharpe (MRS) medium, modified reinforced clostridial medium $(\mathrm{mRCM})$, and modified reinforced clostridial medium-pyruvate (mRCM-PYR) after anaerobic incubation at $44^{\circ} \mathrm{C}$ for $72 \mathrm{~h}$. 
enumerating $L$. delbrueckii ssp. bulgaricus in a mixed culture. The versatility of mRCM-PYR also makes it highly suitable for the study and rapid cultivation of
L. delbrueckii ssp. bulgaricus. Thus, mRCM-PYR is recommended as a growth medium for the isolation and enumeration of $L$. delbrueckii ssp. bulgaricus from

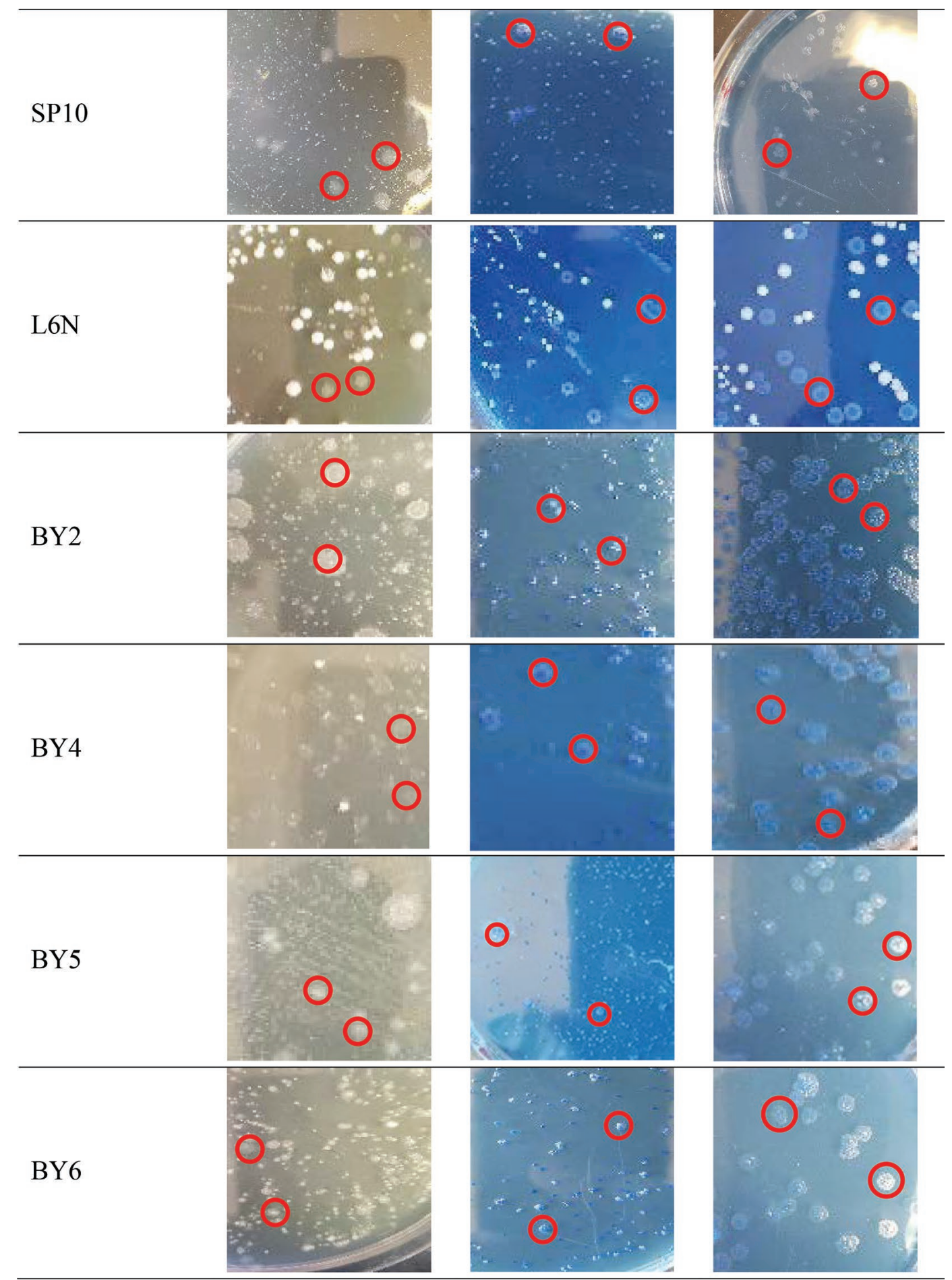

Figure 6 (Continued). Morphology of Lactobacillus bulgaricus (circled) in mixed culture on de Man, Rogosa, and Sharpe (MRS) medium, modified reinforced clostridial medium (mRCM), and modified reinforced clostridial medium-pyruvate (mRCM-PYR) after anaerobic incubation at $44^{\circ} \mathrm{C}$ for $72 \mathrm{~h}$ 
different sources due to this medium's inhibitory effect on the growth of other LAB.

\section{ACKNOWLEDGMENTS}

This publication was made possible by grant number NC.X-267-5-12-170-1 from the National Institute of Food and Agriculture (NIFA, Kansas City, KS) and in part by NIZO Food Research BV (Ede, the Netherlands), Jarrow Formulas (Los Angeles, CA), and the Department of Family and Consumer Sciences and the Agriculture Research Station at North Carolina Agriculture and Technical State University (Greensboro, NC). The authors have not stated any conflicts of interest.

\section{REFERENCES}

Chervaux, C., S. D. Ehrlich, and E. Maguin. 2000. Physiological study of Lactobacillus delbrueckii ssp. bulgaricus strains in a novel chemically defined medium. Appl. Environ. Microbiol. 66:5306-5311. https://doi.org/10.1128/AEM.66.12.5306-5311.2000 http://www .ncbi.nlm.nih.gov/pmc/articles/PMC92460/.

Davis, J. G., and T. McLachlan. 1974. Yogurt in the United Kingdom: Chemical and microbiological analysis. Dairy Industries 39:149177.

de Man, J. C., M. Rogosa, and M. E. Sharpe. 1960. A medium for the cultivation of lactobacilli. J. Appl. Bacteriol. 23:130-135. https:// doi.org/10.1111/j.1365-2672.1960.tb00188.x

Galat, A., J. Dufresne, J. Combrisson, J. Thépaut, L. BoumgharBourtchai, M. Boyer, and C. Fourmestraux. 2016. Novel method based on chromogenic media for discrimination and selective enumeration of lactic acid bacteria in fermented milk products. Food Microbiol. 55:86-94. https://doi.org/10.1016/j.fm.2015.11.005.

Ghoddusi, H. B., and R. K. Robinson. 1996. Enumeration of starter cultures in fermented milks. J. Dairy Res. 63:151-158. https://doi .org/10.1017/S0022029900031629.

Hamann, W. T., and E. H. Marth. 1984. Survival of Streptococcus thermophilus and Lactobacillus bulgaricus in commercial and experimental yogurts. J. Food Prot. 47:781-786. https://doi.org/10 .4315/0362-028X-47.10.781.

Hayek, S. A., R. Gyawali, S. O. Aljaloud, A. Krastanov, and S. A. Ibrahim. 2019. Cultivation media for lactic acid bacteria used in dairy products. J. Dairy Res. 86:490-502. https://doi.org/10 $.1017 / \mathrm{s} 002202991900075 x$.

Higashio, K., Y. Yoshioka, and T. Kikuchi. 1977. Symbiosis in yoghurt culture. I. Isolation and identification of a growth factor for Streptococcus thermophilus produced by Lactobacillus bulgaricus. Nippon Nogeikagaku Kaishi 51:209-215. https://doi.org/10.1271/ nogeikagaku1924.51.4_209.

Lee, S. Y., E. R. Vedamuthu, C. J. Washam, and G. W. Reinbold. 1974. An agar medium for the differential enumeration of yogurt starter bacteria. J. Milk Food Technol. 37:272-276. https://doi .org/10.4315/0022-2747-37.5.272.

Li, C., G. F. Zhang, X. Mao, J. Y. Wang, C. Y. Duan, Z. J. Wang, and L. B. Liu. 2016. Growth and acid production of Lactobacillus delbrueckii ssp. bulgaricus ATCC 11842 in the fermentation of algal carcass. J. Dairy Sci. 99:4243-4250. https://doi.org/10.3168/ jds.2015-10700.

Lourens-Hattingh, A., and B. C. Viljoen. 2001. Yogurt as probiotic carrier food. Int. Dairy J. 11:1-17. https://doi.org/10.1016/S0958 -6946(01)00036-X.

Mahmood, T., T. Masud, S. Ali, K. S. Abbasi, and M. Liaquat. 2015. Optimization and partial characterization of bacteriocin produced by Lactobacillus bulgaricus-TLBFT06 isolated from Dahi. Pak. J. Pharm. Sci. 28:549-555.

Matalon, M. E., and W. E. Sandine. 1986. Improved media for differentiation of rods and cocci in yogurt. J. Dairy Sci. 69:2569-2576. https://doi.org/10.3168/jds.S0022-0302(86)80702-0.

Nwamaioha, N. O., and S. A. Ibrahim. 2018. A selective medium for the enumeration and differentiation of Lactobacillus delbrueckii ssp. bulgaricus. J. Dairy Sci. 101:4953-4961. https://doi.org/10 $.3168 /$ jds.2017-14155.

Pescuma, M., E. M. Hébert, T. Haertlé, J.-M. Chobert, F. Mozzi, and G. F. de Valdez. 2015. Lactobacillus delbrueckii ssp. bulgaricus CRL 454 cleaves allergenic peptides of $\beta$-lactoglobulin. Food Chem. 170:407-414. https://doi.org/10.1016/j.foodchem.2014.08 .086 .

Polak-Berecka, M., A. Waśko, M. Kordowska-Wiater, M. Podleśny, Z. Targoński, and A. Kubik-Komar. 2010. Optimization of medium composition for enhancing growth of Lactobacillus rhamnosus PEN using response surface methodology. Pol. J. Microbiol. 59:113-118. https://doi.org/10.33073/pjm-2010-017.

Robinson, R. K., and A. Y. Tamime. 1976. Quality appraisal of yoghurt. Int. J. Dairy Technol. 29:148-155. https://doi.org/10.1111/ j.1471-0307.1976.tb00422.x.

Singh, J., A. Khanna, and B. Chander. 1979. Antibacterial activity of yogurt starter in cow and buffalo milk. J. Food Prot. 42:664-665. https://doi.org/10.4315/0362-028X-42.8.664.

Tabasco, R., T. Paarup, C. Janer, C. Peláez, and T. Requena. 2007. Selective enumeration and identification of mixed cultures of Streptococcus thermophilus, Lactobacillus delbrueckii ssp. bulgaricus, L. acidophilus, L. paracasei ssp. paracasei and Bifidobacterium lactis in fermented milk. Int. Dairy J. 17:1107-1114. https://doi .org/10.1016/j.idairyj.2007.01.010.

Yamani, M. I., and S. A. Ibrahim. 1996. The differential enumeration of Lactobacillus delbrueckii subspecies bulgaricus and Streptococcus salivarius subspecies thermophilus in yogurt and labneh using an improved whey medium. Int. J. Dairy Technol. 49:103-108. https: //doi.org/10.1111/j.1471-0307.1996.tb02500.x.

Yuksekdag, Z. N., and B. Aslim. 2008. Influence of different carbon sources on exopolysaccharide production by Lactobacillus delbrueckii ssp. bulgaricus (B3, G12) and Streptococcus thermophilus (W22). Braz. Arch. Biol. Technol. 51:581-585. https://doi.org/10 $.1590 /$ S1516-89132008000300019.

Zhu, Y., L. Xiao, D. Shen, and Y. Hao. 2010. Competition between yogurt probiotics and periodontal pathogens in vitro. Acta Odontol. Scand. 68:261-268. https://doi.org/10.3109/00016357.2010 .492235 .

Zourari, A., J. P. Accolas, and M. J. Desmazeaud. 1992. Metabolism and biochemical characteristics of yogurt bacteria. A review. Lait $72: 1-34$.

\section{ORCIDS}

Ayowole Oyeniran (๑ https://orcid.org/0000-0002-7458-7575 Salam A. Ibrahim @ https://orcid.org/0000-0001-5395-9993 Rabin Gyawali @ https://orcid.org/0000-0003-1782-1772 